\title{
Professional Development: Proposition of a Trans-occupational Model from a Qualitative Study
}

\author{
Helenita de Araujo Fernandes ${ }^{1}$ (1) https://orcid.org/0000-0003-3994-3922 \\ Luciana Mourão ${ }^{2}$ (1) https://orcid.org/0000-0002-8230-3763 \\ Sônia Maria Guedes Gondim² (1) http://orcid.org/0000-0003-3482-166X
}

\begin{abstract}
Knowing the perceptions of people from different professions about their professional development is one of the current changes in the field of Labor Psychology. The objective of this study was to construct a Trans-occupational theoretical model of professional development based on the grounded theory. To this end, 25 interviews were conducted in depth with five professional categories, namely: lawyers, entrepreneurs, engineers, physicians and psychologists. Data collection instrument was an open script for interviews, which were then recorded and transcribed. Analysis of results was supported by the software Alceste. Results point to similarities and specificities in the career trajectories inter-professions, and we opted for the non-inclusion of entrepreneurs in the model due to their significant difference when compared to the other categories. As a conclusion, we proposed a trans-occupational model of professional development with five key elements: Work Context, Motivation, Training/Learning, Relational Elements and Lived Experiences. The model, although it requires research for validation, offers relevant contributions and reflections to professionals and researchers working in the area.
\end{abstract}

Keywords: professional development, learning at work, professions

\section{Desenvolvimento Profissional: Proposição de um Modelo Transocupacional a Partir de Estudo Qualitativo}

Resumo: Conhecer as percepções das pessoas de diferentes profissões acerca do seu desenvolvimento profissional é um dos desafios atuais da área de Psicologia do Trabalho. O objetivo deste estudo foi construir um modelo teórico transocupacional de desenvolvimento profissional baseado na teoria fundamentada (Grounded Theory). Para tanto, foram realizadas 25 entrevistas em profundidade, com cinco categorias profissionais, a saber: advogados, empresários, engenheiros, médicos e psicólogos. O instrumento de coleta de dados foi um roteiro aberto para entrevistas, que foram gravadas e transcritas. A análise dos resultados foi apoiada pelo software Alceste. Os resultados apontam para similitudes e especificidades nas trajetórias de carreira interprofissões e optou-se pela não inclusão dos empresários no modelo pela expressiva diferença em relação às demais categorias. Como conclusão, propusemos um modelo transocupacional de desenvolvimento profissional, com cinco elementos centrais: Contexto de trabalho, Motivação, Formação/aprendizagem, Elementos relacionais e Experiências vividas. O modelo, embora careça de pesquisas que o valide, oferece contribuições e reflexões relevantes para os profissionais e pesquisadores que atuam na área.

Palavras-chave: desenvolvimento profissional, aprendizagem no trabalho, profissões

\section{Desarrollo Profesional: una Propuesta de Modelo Transocupacional a partir de un Estudio Cualitativo}

\begin{abstract}
Resumen: Uno de los desafíos actuales del campo de Psicología del Trabajo es conocer las percepciones de individuos de diferentes profesiones acerca de su desarrollo profesional. El presente estudio propone construir un modelo teórico transocupacional de desarrollo profesional desde la teoría fundamentada (Grounded Theory). Para ello, se realizaron 25 entrevistas en profundidad con las siguientes cinco categorías profesionales: abogados, empresarios, ingenieros, médicos y psicólogos. En la recopilación de datos se utilizó como instrumento un guion abierto para las entrevistas, que fueron grabadas y transcriptas. En el análisis de los resultados se utilizó el software Alceste. Los resultados apuntan similitudes y especificidades en las trayectorias de carreras interprofesiones, y en el modelo se optó por la no inclusión de la categoría empresarios debido a la expresiva diferencia en relación con las demás categorías. Como conclusión, proponemos un modelo transocupacional de desarrollo profesional con cinco ejes centrales: Contexto laboral, Motivación, Formación/Aprendizaje, Elementos relacionales y Experiencias. Aunque necesita más investigaciones para validarlo, el modelo ofrece aportes y reflexiones relevantes a los profesionales e investigadores que actúan en este campo.
\end{abstract}

Palabras clave: desarrollo profesional, aprendizaje en el trabajo, profesiones

${ }^{1}$ Universidade Salgado de Oliveira, Niteroi-RJ, Brazil
${ }^{2}$ Universidade Federal da Bahia, Salvador-BA, Brazil

Article derived from the doctoral dissertation of the main author, under supervision of the first,defended in 2018 at the Graduate Program in Psychology of the Salgado de Oliveira University. With support by the Coordination for the Improvement of Higher Education Personnel (CAPES) - Funding Code 001.

Correspondence address: Luciana Mourão. Universidade Salgado de Oliveira. R. Marechal Deodoro, 217, 2nd floor, Niteroi-RJ, Brazil. Zip-code 24.030-060. Email: mourao.luciana@gmail.com
A profession requires expertise, guidelines, rules of conduct, minimum or expected qualification and performance criteria, based on a set of practices (American Psychological Association [APA], 2010). Professional Development (PD), however, does not depend only on the normative definitions of a profession, as it involves an individual process of learning its expertise, skills and attitudes over time and its 
related use in work situations, in the form of professional skills (Paquay, Wouters, \& Van Nieuwenhoven, 2012).

Formal training and experiential learning are, therefore, fundamental to the acquisition of skills that characterize the PD. The first mainly focus on the beginning of the career and on elements related to the training and socialization typical of a profession. Experiential learning, in turn, arises from critical actions and reflections of the workers on their professional routine, increasing the capacity for self-development (Kolb, 1984; Pimentel, 2007). In this sense, work learning is favored by skills such as learning to know, to do, to live together with others and to be (Abbad, Loiola, Zerbini, \& Borges-Andrade, 2013), also involving interaction with the context (Bell, Tannenbaum, Ford, Noe, \& Kraiger, 2017).

The Dictionary of Psychology of the American Psychological Association - APA introduces the concept of $\mathrm{PD}$ as the continuous training or education required from people who work in a given profession, being associated with Career Development (APA, 2010). Such definition has two limitations. Firstly, it associates PD exclusively to situations of formal employment and, secondly, it only considers formal education actions as constituent elements of such development. However, the APA definition is useful for pointing out an underlying logic to the $\mathrm{PD}$, which considers various issues faced by the individual depending on career stage (APA, 2010).

This study adopted the PD definition presented by Mourão, Porto and Puente-Palácios (2014), understood as a process of acquisition and improvement of knowledge, skills and attitudes that favor work performance and individual advancement in the career. We opted for this definition due to the following reasons: (i) the procedural character attributed to the phenomenon; (ii) the relationship expressed with the acquisition and improvement of knowledge, skills and attitudes since such attributes are dynamic and require renewal over time; (iii) the connection to career advancement and work performance, and (iv) the scope of the concept, by encompassing different work situations and not only those linked to formal employment.

It is assumed, then, that PD has a relationship with work performance (Campbell \& Wiernik, 2015; Malhotra \& Singh, 2016) and requires the acquisition and improvement of skills, including formal and informal learning processes driven by contextual, individual and relational elements. Examples of contextual aspects would be the workplace, support from leadership and colleagues, information received, instructors, environment characteristics, and the offering of programs aimed at work learning, as communities of practice and mentoring (Abbad et al., 2013; Santos \& Pais, 2014). Individual elements, in turn, would involve needs, motivation, self-efficacy, resilience, and learning strategies of apprentices (Monteiro \& Mourão, 2017). Relational elements, however, are related to what is learned from various actors within and outside the workplace, whether through vicarious learning - from observation - or via different exchanges established among people in their professional relationships (Bandura, 1977; Illeris, 2011; Santos \& Pais, 2015).
The connection between formal training, work learning and PD through methods that facilitate experiential learning is present in the literature (Dobos, 2014; Stewart, 2014), as well as studies relating formal and informal education at work to the development of human capital (Noe, Clarke, \& Klein, 2014). In this sense, the PD might be associated both to strategies managed by work organizations as to career self-management strategies (Gallardo-Gallardo, Nijs, Dries, \& Gallo, 2015), with personal experiences that are present in both cases.

Such experiential learning requires a process that goes through four main levels: differentiation, acquisition, specialization and integration (Kolb, 1984). Differentiation consists of levels of professionalism; professional identity; structure of consciousness; space occupied in life; concrete experience; reflective observation; abstract conceptualization, and active experimentation. Acquisition emphasizes the performance; the cognitive development of doing; responses, actions, tasks, considering immediate objectives of achieving goals. Specialization, in turn, has an emphasis on learning; reasons that lead to doing; interpretive vision, admitting and process of learning to learn, which involves the transformation of goals and strategies. Finally, integration focuses on development; reflections on how to enhance their own doing, with broad goals aimed at a purpose of life and integrative action, considering career, life and generations (Pimentel, 2007).

Similarly to Kolb (1984), Illeris (2011) also presents of model of work learning that considers experiential learning. Such model assumes three dimensions of learning: content, incentive, and context. The constitutive logic of this proposal is that essential work learning assumes the character of skill development and arises from the acquisition of certain technical skills and from the interaction between practice and elements of the subject's work identity.

Therefore, the theoretical framework allows one to state that PD involves different types of learning and career moments (Mourão et al., 2014; Paquay et al., 2012). The identification of individual, interactional and contextual elements in work learning (Illeris, 2011) leads to the expectation that, despite some peculiarities, different professions present common propellants for $\mathrm{PD}$, and one can build a trans-occupational model for PD that represents similarities in the trajectory of distinct professionals in various occupations. The concern in developing a trans-occupational model of PD is supported by the increased emphasis given to trans-professional collaborative learning (Högdin \& Kjellman, 2014) and by a literature review on PD that identifies the absence of general models (Monteiro \& Mourão, 2017).

Thus, this study aimed precisely at building a transoccupational theoretical model of PD, one that contemplates the similarities of evolutionary career processes in different professions. As intermediate goals of the research, we intended to: (i) identify core elements of the PD of five occupational categories (lawyers, entrepreneurs, engineers, physicians and psychologists); (ii) analyze similarities and differences related to these categories' PD; (iii) propose links between elements from qualitative data that comprise an initial theoretical model of PD for different occupations, and 
(iv) infer procedural aspects of the PD of the five categories in the light of Kolb's theoretical model.

The relevance of proposing a general models meets not only the increasing interest in the subject (Hill, Beisiegel, \& Jacob, 2013; Monteiro \& Mourão, 2017) but also arises from the recognition that society and organization need skilled workers to generate wealth, maintaining competitiveness and effectiveness (Abbad et al., 2013). Through PD, workers can maintain employability and advance in their career (Mourão et al., 2014).

In addition, the proposition of a theoretical model on PD from a qualitative study is justified because a series of questions remain unanswered in the literature, including possible similarities and differences in the process of developing distinct professional categories since the current research focus on specific categories (Monteiro \& Mourão, 2017). Furthermore, there is little systematic knowledge on the processes involved in career trajectories. In this sense, a theoretical model can serve as raw material for researchers, training institutions and professionals who work with talent management (Claussen, Grohsjean, Luger, \& Probst, 2014), allowing for a review of current practices and for activities more consistent with results of scientific research.

Thus, considering the relevance of proposing a general theoretical model of PD, we started from the theoretical proposition of Kolb (1984) and from primary data obtained through interviews with professionals from different categories, using the methodological approach of the grounded theory, which can be used to merge new observations with the existing theory, pointing to other perspectives that best explain a given phenomenon (Woo, O'Boyle, \& Spector, 2017). Regarding PD, this is especially important because the organizational science is too invested in a "top to bottom" deductive approach, without the creation or expansion of theoretical models, which has limited the advancement of scientific production in the area (Murphy, Klotz, \& Kreiner, 2017; Spector, Rogelberg, Ryan, Schmitt, \& Zedeck, 2014).

In this sense, the grounded theory was used in this study as a methodological tools that could broaden the dialogue between existing theories and data collected in interviews with professionals from different backgrounds and occupations. We hope this deductive-inductive and inductivedeductive dialogue brings about elements to discuss the theory, considering the specificities of career trajectories. While it may seem contradictory to take on deductive and inductive elements jointly, the exploratory data analysis is considered to be a foundation of inductive research (Jebb, Parrigon, \& Woo, 2017). In addition, classical authors of the grounded theory, as Glaser and Strauss (1967), point out the hybrid character of it, in the sense of covering inductive and deductive approaches so as to produce theories that emerge from initial incursions in misunderstood fields of research. The purpose of this article is, therefore, to contribute so that further deductive studies in the field of Organizational and Labor Psychology can be based in inductive-deductive studies rather than relying on "pseudo-theories," with explanations based on conjecture and personal opinions (Cucina \& McDaniel, 2016).

Hence, the procedure adopted was that of an open coding from data of interviews (provisional categorical system of data reduction) and from constant comparison (data and existing theory), to sought a sense for data and perform inferences to the phenomenon studied. Thus, this study aimed at seeking elements to discuss and expand an existing theoretical model (Kolb, 1984), allowing for the improvement and theoretical sophistication, based on the triad theory-phenomenon-data. The methodological tool chosen for such discussion of theory-data was the grounded theory (Woo et al., 2017). We sought to meet the four fundamental principles that distinguish the grounded theory from a simple induction exercise: emergency, constant comparison, theoretical sampling, and theoretical saturation (Charmaz, 2014; Walsh et al., 2015), as will be discussed below.

Considering these features of the grounded theory and the literature review presented, the central question of this study, whose answer would generate inputs for this theoretical development, was: "What elements lead to PD if different occupations are considered?". The next session provides methodological information on how we sought to answer that question, detailing participants, instruments and procedures of data collection and analysis.

\section{Method}

The study reported here is characterized as an exploratory, qualitative research, using the methodological approach of the grounded theory (Charmaz, 2007; Glaser \& Strauss, 1967). Data were obtained through interviews conducted with professionals in five areas. The method of theoretical construction consists of the dialogue between data-theory-data (constant comparison method), requiring from the analytical process a deepening in the specific field of the object under study, without losing sight pf a more general conceptual frame of the phenomenon.

\section{Participants}

Participants come from five professional categories - lawyers, entrepreneurs, engineers, physicians and psychologists. Five interviews were conducted with professionals of each category, totaling 25 interviewees, all residents in the city of Rio de Janeiro. The initial number of interviews was defined as an estimate of the extent and expenditure of resources with observations, from the prediction of saturation point based in two indicators (Thiry-Cherques, 2009), minimum two years of professional practice and diverse experiences by professional category (lawyers working in different branches of Law, physicians and psychologists with different specialties etc.). The total number of interviewees was to be expanded if theoretical saturation was not achieved. Participants were, thus, chosen in a non-random manner, seeking diversification. As stated, one of the criteria for inclusion in the study was the 
minimum of two years of practice in the working area, so as to set some level of PD. Once the number predicted for initial collection was achieved, a preliminary reading of the interviews by professional category was conducted to assess the potential of the corpus for the desired analysis. One could assess the transcribed material contemplated different perspectives in each occupational category,being enough to compose a corpus that could be subjected to qualitative analysis and with chances of achieving the study goals, from the estimated saturation. Therefore, one concluded there was no need to increase the sample.

Participants varied regarding time since training, working experience and practice in the area, with a maximum of 47 years. They were also distributed by sex (11 women and 14 men) and engineering and entrepreneurship professions had the lower female representation (only one woman each), whereas Psychology had the largest number of women (four). Regarding activity sector, entrepreneurs and lawyers studied worked exclusively in the private sector, whereas other participants varied between private and public sector, with one engineer and two psychologists working in the public sector and four physicians acting in both sectors. Except for entrepreneurs, all the other participants had links with labor organizations - eight of them large-size and the rest being middle- or small-sized organizations. As for education level, all participants had undergraduate studies and 19 of them had graduate degrees, four of them at a stricto sensu level (Table 1).

Table 1

Details of the study sample

\begin{tabular}{|c|c|c|c|c|c|c|c|c|}
\hline \multirow{2}{*}{ 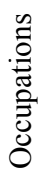 } & \multirow[b]{2}{*}{ Area } & \multicolumn{5}{|c|}{ Time (in years) } & \multirow[b]{2}{*}{ Sector } & \multirow[b]{2}{*}{ Education level } \\
\hline & & $\begin{array}{l}\stackrel{9}{0} \\
\stackrel{0}{0} \\
\stackrel{\overrightarrow{0}}{0}\end{array}$ & 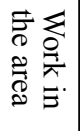 & 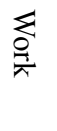 & $\underset{\mathscr{x}}{\mathscr{Q}}$ & 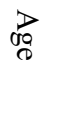 & & \\
\hline \multirow{5}{*}{ 㐫 } & Trade unionist & 15 & 20 & 20 & $\mathrm{~F}$ & 38 & Private & Graduate studies \\
\hline & Labor and environmental & 10 & 10 & 28 & M & 45 & Private & Graduate studies \\
\hline & Tax law & 25 & 25 & 25 & M & 50 & Private & Undergraduate education \\
\hline & Family and labour & 10 & 15 & 24 & $\mathrm{~F}$ & 41 & Private & Master's degree \\
\hline & Civil law & 02 & 02 & 24 & M & 49 & Private & Doctorate \\
\hline \multirow{5}{*}{ 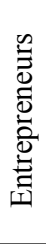 } & Chemical industry & 14 & 17 & 17 & M & 36 & Private & Graduate studies \\
\hline & Automation Engineering & 26 & 30 & 30 & M & 48 & Private & Graduate studies \\
\hline & Training services & 48 & 18 & 47 & M & 74 & Private & Graduate studies \\
\hline & Advertising services & 10 & 13 & 20 & M & 37 & Private & Undergraduate education \\
\hline & HR Consulting & 15 & 4 & 25 & $\mathrm{~F}$ & 48 & Private & Graduate studies \\
\hline \multirow{5}{*}{ 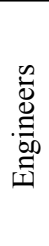 } & Electronic & 12 & 12 & 12 & M & 35 & Private & Master's degree \\
\hline & Telecommunications & 2 & 2 & 5 & M & 31 & Private & Undergraduate education \\
\hline & Electrical & 10 & 10 & 12 & M & 34 & Private & Graduate studies \\
\hline & Chemical/Petroleum & 09 & 08 & 08 & $\mathrm{~F}$ & 35 & Public & Master's degree \\
\hline & Mechanic & 02 & 02 & 05 & M & 27 & Private & Undergraduate education \\
\hline \multirow{5}{*}{ 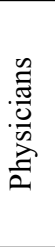 } & Occupational medicine & 16 & 15 & 15 & $\mathrm{~F}$ & 38 & Public. and Private & Graduate studies \\
\hline & Family medicine & 10 & 9 & 9 & $\mathrm{~F}$ & 34 & Public. and Private & Graduate studies \\
\hline & Pediatrician & 22 & 22 & 22 & $\mathrm{M}$ & 47 & Public. and Private & Undergraduate education \\
\hline & Psychiatrist & 41 & 41 & 41 & M & 67 & Private & Undergraduate education \\
\hline & Sports & 30 & 30 & 35 & $\mathrm{~F}$ & 55 & Public. and Private & Graduate education \\
\hline \multirow{5}{*}{$\begin{array}{l}0 \\
0 \\
00 \\
00 \\
0 \\
0 \\
0 \\
0 \\
0 \\
0 \\
0\end{array}$} & Consultant & 34 & 34 & 34 & $\mathrm{~F}$ & 59 & Private & Graduate education \\
\hline & School psychologist & 33 & 23 & 33 & $\mathrm{~F}$ & 56 & Private & Graduate education \\
\hline & Occupational Health & 18 & 4 & 20 & $\mathrm{~F}$ & 42 & Public & Graduate education \\
\hline & Hospital & 19 & 2 & 36 & $\mathrm{~F}$ & 49 & Private & Graduate education \\
\hline & Staff selection & 32 & 32 & 36 & M & 54 & Public & Graduate education \\
\hline
\end{tabular}




\section{Instruments}

An open script was used for the interviews, with guidequestions related to professional trajectory. Questions allowed for the interviewee to organize their statement more freely, as shown below: (i) Tell me about your professional trajectory, how did you start your career and which professional changes have you lived; (ii) What reasons lead you to pursue this profession?; and (iii) In a reflection on your professional path, what elements would you single out as most decisive for your process of professional growth? Other questions were made from the answers obtained; hence, the course of interviews varied, but the overall focus remained on $\mathrm{PD}$.

\section{Procedures}

Data collection. The research was approved by the Research Ethics Committee of a University under opinion: CAEE 39705114.2.0000.5289 (Brazil Platform). Interviews were audio recorded, with due consent by the participants, and subsequently transcribed in full. The average duration of each interview was 115 minutes.

Research participants were all volunteers and signed the Informed Consent Form. Prior to data collection, participants were informed on the secrecy of their responses and the purpose of recording. Keeping such commitment, any references to names of people or institutions have been removed from the illustrative statements. Data collection was performed by the main author, whereas the interviews and literal transcriptions of the recordings were conducted by a duly trained research team.

Data analysis. Analysis was made with support of the software Alceste 2010, which conducts textual analysis, allowing one to sort, synthesize and identify the topical organization of a text by accessing the existing relations between lexicons. Five textual corpus were built, one by professional category, each with five Initial Context Units (i.c. $u_{s}$ ), corresponding to the interviews. The i.c.u are the starting point of the analysis carried out by the software, which uses the Chi-square value to identify the frequency of co-occurrences and organizes them into larger units, called Elementary Context Units (e.c.u $\mathrm{s}_{\mathrm{s}}$. Alceste-generated reports present the classes identified and the words representative of each class, in addition to performing a factorial analysis by correspondence, which allows the viewing of inter-class distance and proximity areas. Such analysis is based on the identification of word co-occurrence (quantification), signaling meaning similarities (quality), aimed at proposing groups (clusters) that guide the interpretation of textual material.

The analysis is, therefore, in line with the original proposal of the grounded theory by Glaser and Strauss (1967), which suggest the connection between qualitative and quantitative data. The material inductively generated by Alceste requires active interpretation by the researcher, who must assign names to each of the classes and describe them so as to bind data (statements of professionals about their
PD trajectories) to the basic theory, giving them meaning. Methodological principles that guide the use of the grounded theory are extremely useful in this process of inductivedeductive and deductive-inductive dialogue, allowing for theory construction and refinement (Glaser \& Strauss, 1967; Woo et al., 2017).

\section{Results}

Based on the results of Alceste analysis, the key aspects of $\mathrm{PD}$ that predominated in the narratives about professional trajectories of the different occupational categories researched are presented. Comparison of consensus and dissents regarding these categories showed that entrepreneurs presented PD-related classes that were very distinct from that of other professions. Possible reasons for this may be associated to the fact this is an occupational category that does not require specific professional training and to the particularity that entrepreneurs' $P D$ is related to the growth of their respective companies. We decided, then, by deleting the data of this category from the trans-occupational model proposed in this research.

Whereas 20 interviews remained after such delimitation and it would not be possible to report in this article the results obtained in full, a summary of results will be presented below, initially considering the specifics of vision of psychologists, physicians, engineers and lawyers. The joint analysis of these categories for the proposition of a trans-occupational model is presented in the Discussion section. Thus, a initial part of the analysis will be focused on more concrete aspects arising from the statements, while the next step (discussion) presents a more abstract analysis, pointing the possible contributions to the phenomenon studied.

\section{PD of Psychologists}

Alceste revealed three classes representing the narratives about psychologists' trajectories. Class 1 - Motivation is the most prominent (59\% of the corpus), followed by Class 3 - Work Context (29\%) and Class 2 - Training/Learning $(12 \%)$. The first of these covers aspects that lead the person to wanting to develop and that relate to professional identity, including feelings. Some of the most frequent words were: professional, autonomy, problem, challenge, moment, patient, learning, pride, achievement, life, feeling, mind, conversation. An example of how these words appear in the accounts of trajectory by psychologists:

Every day I feel like that, I go home and say: Man, how proud I am of myself! Because I'm passionate about what I do, I feel very much fulfilled by it, I like this thing of challenge, of novelty ..., at the hospital, you meet people in bed saying things like: 'I'm not eating anymore, please turn off these buttons, I don't want to live anymore" and when you enter the room and chat ... when you start a conversation, because 
often the patient won't even talk (Hospital Psychologist, 26 years of profession).

Class 3 - Work Context, the second most representative in the corpus, discusses aspects of learning in the workplace. Some frequent words were: area, resources, human, work, opportunities, organizational, company, project, advice, research, area, quality and participation. An example reveals the association of such words: "I had a chance to be monitor in the clinical and business areas. But I started doing a lot of internships in the business area, and greater opportunities arose for that field" (Consulting Psychologist, 34 years of profession).

Class 2 - Training/Learning, less representative but still present in the corpus of psychologists, is closer to Class 3 than to Class 1. It brings aspects related to a dialogue between formal learning from initial training and from experiences of professional practice. Words such as internship, consultant, health, therapy, education, resume, study, beginning, clinic, childhood, mean and daycare center appear more often. An illustrative statement allows one to visualize the context of the statements in which some of these words appear:

I spent all this time in the daycare center, finding it really cool. They even had literacy training there. And it was great because I learned a lot by working with the parents, more so with the children, guiding teachers of early childhood education, when I started, ... but now I want to focus my attention on elementary school, then I gave my resume to some schools (School Psychologist, 33 years of profession).

\section{PD of Physicians}

Alceste revealed there are four classes representing the narratives about physicians' trajectories. Class 1 - Work Context is the most representative ( $40 \%$ of the corpus), being an axis separated from the other classes. Class 4 - Relational Elements (25\%) and Class 3 - Motivation (23\%) follow. Class 2 - Training/Learning (12\%) is the less representative in the statements of this professional category.

The Class 1 - Work Context shows that learning is related to medical practice. The most frequent words were: undergraduate, graduate, civil service examination, salary, Medicine, hospital, places, residency, public network, private network, municipality, opportunities, infirmary. An example of use of some of the words in the context of the narratives would be: 'I'd undergraduate in 1999, tried for a residency but hospitals were stretched pretty thin ... Then I took a civil service examination for the municipality, for the State, awful places to work ..." (Labor Physician, 15 years of profession).

Class 4 refers to learning from interpersonal relationships and different actors involved in the routine of physicians. Some of the most frequent words were: difficulties, help, child, team, organization, doctor, rules, different, boss, best. A snippet of speech that illustrates the use of these words in physicians' statements would be:
College taught me how to deal with differences, and us doctors deal with a lot of different people; the main thing, I guess, is to be able to get along. I was the boss for a long time, so I had some difficulties I managed to surmount because I was always able to relate well with other people (Pediatrician, 22 years of profession).

Class 3 - Motivation approaches Class 4 when addressing aspects of work learning, but brings elements of personal expectations and reflections on choices made and paths traversed. The most frequent words were: time, money, pay, confidence, book, change, world, pleasure, business. An illustrative example:

The important thing is for you to define something you like, something you take pleasure from. One should never do something only for the money or the status ... as time goes by, I'm becoming a more experienced, confident professional (Psychiatrist, 41 years of profession).

Class 2 - Training/Learning, although less representative within the corpus, brings reflective elements about what one learns from work experiences and opportunities offered at work. It reflects on technical aspects of medical knowledge and their professional experience. The words that appeared the most were: profession, age, concept, emergency, important, experience, area, assessment, preparation, autonomy, video, actual, body, physical, human, patient, society, professional, knowledge. An example that may clarify the content of this class is:

There are four clinicians, right, they actually have an experience in emergency; although I have done emergency enough, they went deeper. ... I do videos, right, to illustrate, to unite it all, so that people have an idea on how the body works" (Sports Physician, 35 years of profession).

\section{PD of Engineers}

Data analysis indicated four classes representing the narratives of engineers' trajectories. Class 2 - Work Context is the most representative in the corpus (38\%), forming a separate axis from the other classes. Class 1 - Training/ Learning is the second most representative (36\%), followed by Class 3 - Relational Elements and Class 4 - Lived Experiences, each representing $13 \%$ of the corpus.

Class 2 - Work Context brings a technical facet, related to the learning that occurs in professional practice. Words such as probe. knowing, manager, chief, onboard, obstacle, fast and contract are prevalent. Here is an illustrative example of the discourses: "Working onboard is not easy, it is a difficult environment, there a lot at stake, if you have a family it gets even more complicated ... I don't see much of an obstacle, you know, if the guy is good at what he does" (Mechanical Engineer, five years of profession). 
Class 1 - Training/Learning shows a facet of the trajectory of professional work context, still articulated to formal learning. The most frequent words were: area, project, engineering, opportunity, coach, field, technique, electronics, course, internship, master. A statement that shows the use of such words in the context of the interviewees' narrative would be: Before I undergraduate I was approved in a civil service examination, so I quit the internship, I did, I started my Master's ... I have a Master's degree in a technical area, right, chemical engineering" (Chemical/Petroleum Engineer eight years of profession).

Classes 3 and 4 bring more reflective elements about the trajectory of PD. Class 3 - Relational Elements addresses work learning, emphasizing social interactions. The words that most represented this class were: team, friend, co-worker, talent, coaching, learning, growth, work, professional. Excerpts of a discourse exemplify these aspects: "We're friends, co-workers here because we met at work, but these are people who had an enormous influence, even in my professional attitude" (Electrical Engineer, 12 years of profession).

Class 4 - Lived Experiences, in turn, deals with reflections on learning from attitudes and experiences throughout the career. The prevalent words were: career, beginning, fact, research, training, knowledge, can, dedication, exposed, situation, change. A snippet of a statement may exemplify this class:

These are trainings in which you are exposed to situations and you improve, you know, your non-technical side, and I think that's what counts in the long term ... and I think you learn that much more by experience than in formal training (Electronic Engineer, 12 years of profession).

\section{PD of Lawyers}

Alceste revealed five classes representing the narratives about the trajectories of lawyers. Class organization here is more complex in comparison with the previous professional categories. There is no prevalence of only one class or axis. Axis 1 groups Class 1 - Motivation (15\%), Class 2 - Lived Experiences (18\%) and Class 3 - Professional Routine (26\%), representing $59 \%$ of the corpus. Axis 2 groups Class 4 Training/Learning (13\%) and Class 5 - Work Context (28\%). Except for Classes 1 and 2 - which are close together, the others are located in separate quadrants, revealing specific facets of the narratives.

Class 5 - Work Context, most representative, brings about contextual aspects from reflections about the practice throughout the career in Law. The most frequent words were: performance, profession, goal, choice, autonomy, problem, ability, technique, career, development, change, qualification, obstacle, achievement, trajectory. An example that allow us to illustrate this class would be:

People have autonomy to achieve, with professional competence, a logic qualified performance, seeking their technical ability, believing they're always at the beginning of their career, that there will always be obstacles, that they'll have to overcome them from task prioritization, seeking the solution to each and every problem (Environmental and Labor Lawyer, 24 years of profession).

Class 3 presents the reflection on learning in the Professional Routine. The most frequent words focus on specific aspects of the work of lawyers: worker, client, result, case, critique, complainant, pleasure, wins, conquest, suit, personal gain. An excerpt that exemplifies the use of such words in the context of interviewees' statements would be:

Many colleagues don't like to work with the claimant because of that, you must be patient, you must be tactful. The client is always needy, the client is always lost, the client is always suspicious because, unfortunately, my category is denigrated, isn't it? It has that fame, so you must earn this trust (Labor and Family Lawyer, 24 years of profession).

Class 2 refers to learning from Lived Experiences, revealing the different opportunities the lawyers had on their professional trajectory and that they consider important for their development. The most frequent words were: internship, starting, college, lawyer, moment, process, law office, hearing, resignation. An excerpt that shows the association of these words in statements is:

I didn't do internships in law office because I did not intend to practice law; even though as soon as I had my degree I've done the bar exams, I've passed the bar exam, I had no intention of practicing law. So I did the model law office, which was mandatory, but no internships. For reasons of life, I ended up in a law office and have been practicing law virtually since undergraduate (Union Lawyer, 20 years of profession).

Class 1 refers to the Motivation to work in the career. The most frequent words were: study, limit, work, interested, responsibility, expert, power. Here is an illustrative example: "In my professional development, I think today I'm able to combine work and study in the same purpose, the same field of research; anyway, I think it's a good thing" (Union Lawyers, 20 years of profession).

Finally, Class 4, the least representative among lawyers, brings elements of Training/Learning, with a discourse composed of several terms frequent in academia. Words prevalent in this class were: undergraduate, courses, teaching, institution, academia, students, discipline, law, professor. An example that would illustrate such class: "Be curious, be dedicated, have determination and always seek improvement, don't expect miracles from the undergraduate and graduate professor because much of Law is not legislated" (Tax Lawyer, 25 years of profession). 


\section{Discussion}

The data analysis conducted was based on the use and creation of maps for encoding that were then faced with the theoretical contributions of Kolb (1984), aimed at placing the theory within the contributions of the scientific community (Araujo \& Estramiana, 2011). In this sense, the trans-occupational theoretical model of PD considered the similarities in the professional path of career advancements and improvements of four occupational categories and was constructed from research data, compared to the existing theory, in accordance with principles that guide the grounded theory (Glaser \& Strauss, 1967; Woo et al., 2017).

Although the results indicate differences in the PD processes of the four occupational categories studied (Figure 1), we have also observed similarities in these processes, which allowed the proposition of a trans-occupational theoretical model yet to be perfected. The model highlights the procedural character of PD (Mourão et al., 2014) and innovates by discussing the general model of Kolb. The analysis of trajectories suggests the elements that contribute to PD are related to different moments in the career path.

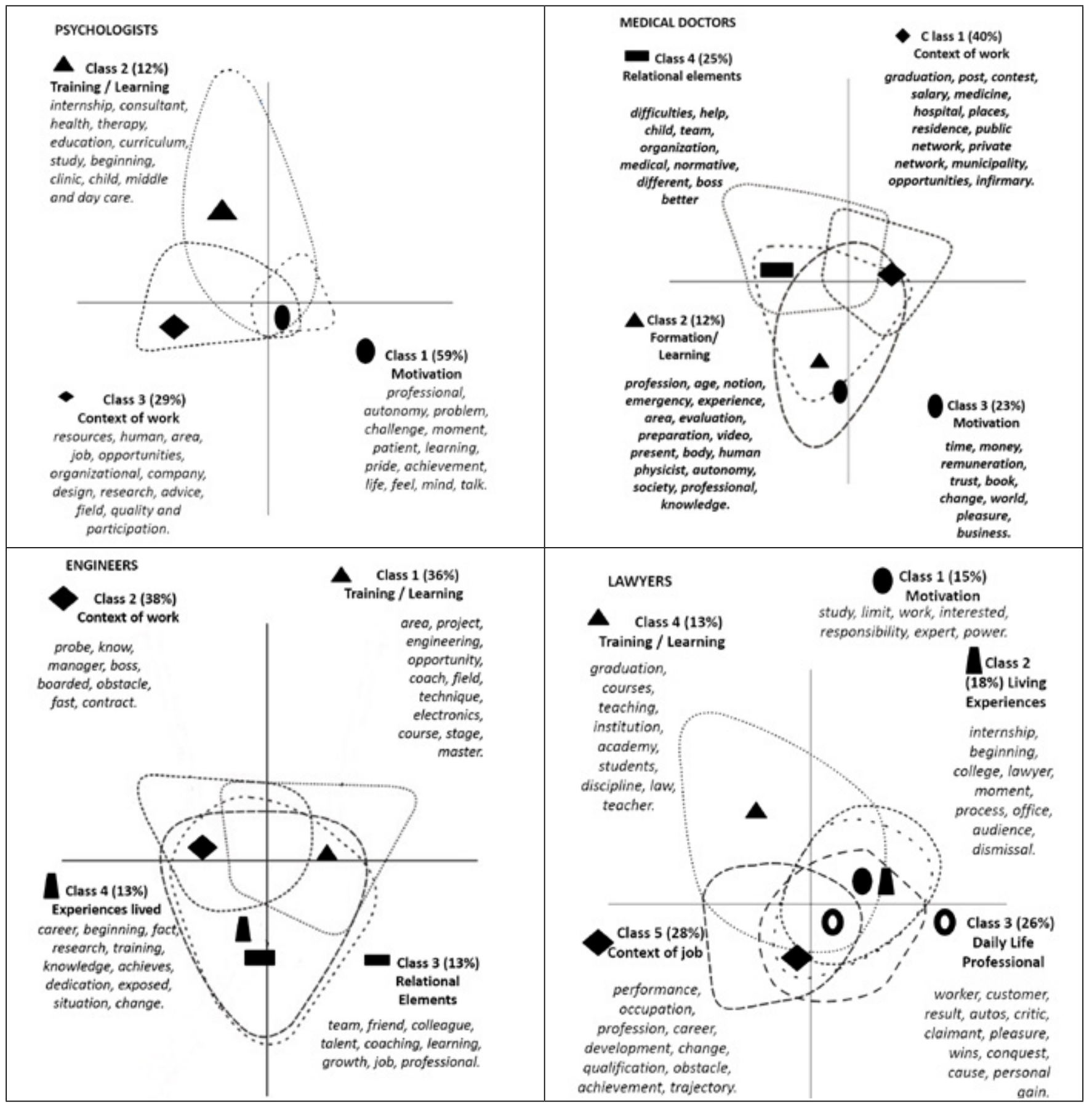

Figure 1. Qualitative factorial analysis for the categories of psychologists, physicians, engineers and lawyers. 
Discourses that characterize the initial phase concerning training and professional insertion present peculiarities regarding the next step of actual career trajectory, when abstract and reflective learning start to have greater emphasis. Thus, in the initial phase, motivational elements and those related to training/learning are prevalent; after that, career growth starts to be driven by lived experiences in the world of work and relational elements, which are characterized by the interaction with different social actors and vicarious learning from observation. The backdrop is the Work context, which exerts influence over the entire career path, both in the initial phase as in subsequent ones.

We highlight the fact that Work context and Training/ Learning characterize the common core of the model, as these classes were identified in the trajectories of all professions studied. Such result is consistent with the literature in the area, which presents a direct result between PD and work performance (APA, 2010; Campbell \& Wiernik, 2015; Malhotra \& Singh, 2016), as well as between PD and learning throughout the career (Illeris, 2011; Kolb, 1984; Monteiro \& Mourão, 2017; Pimentel, 2007). Thus, the common core of PD resulting from this research confirms the own understanding of the concept and the theoretical pillars that sustain the construct (Abbad et al., 2013; APA, 2010; Bell et al., 2017; Mourão et al., 2014; Paquay et al., 2012).

Despite this important similarity, some dissimilarities are identified between occupational categories. Motivation, for instance, emerged as an important element in statements related to the initial PD phase of psychologists, physicians and lawyers, but not engineers. Relational elements, in turn, were present as a class associated to the PD of engineers and physicians but do not arise as a relevant category from the discourses of psychologists, probably due to the clinical emphasis of the profession (Bernardes, 2012), characterized by individualized work practice and little demand of interaction with peers, supervisors or other actors in the working environment. Lived experiences emerge mainly from the discourse of lawyers and engineers, probably because the experience with practice is identified as striking along the career in these professions and, therefore, as an element that drives the PD (Dobos, 2014; Stewart, 2014).

The most extreme case of dissimilarity was the class Professional Routine, which emerged exclusively from the discourse of lawyers. A possible explanation for the emphasis this category gives to routine may be related to the dynamics of this area, focused on inter- and intraprofessional competition, in which the seats occupied by them in the system of professions are factors conditioning their interactions and professional opportunities (Bonelli, 1998). As the objective of this study was the proposition of a trans-occupational model of PD, that is, one to highlight similarities, the class Professional Routine did not remain in the proposed model (Figure 2), as it emerged exclusively from the discourses of lawyers.

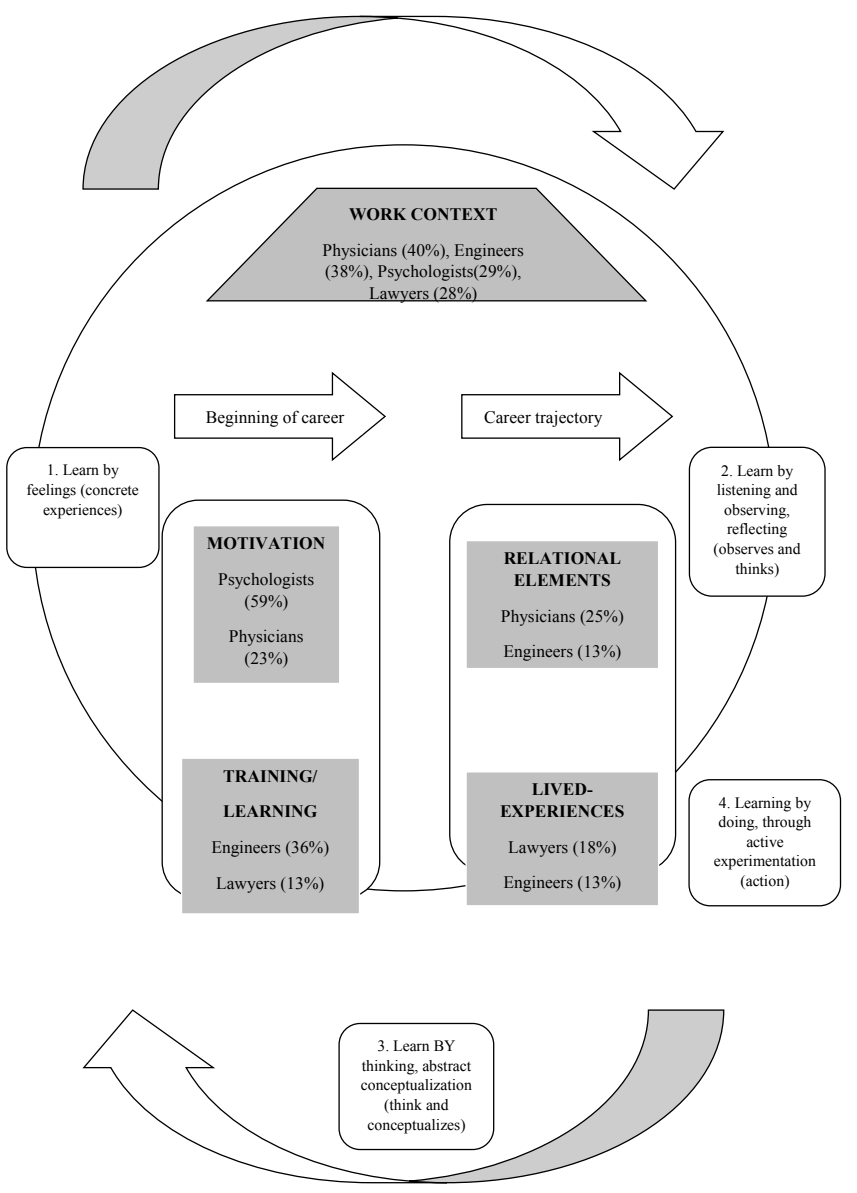

Figure 2. Transocupational model of DP of lawyers, engineers, physician and psychologists

Regarding the use of the grounded theory, the study here reported sought to meet its four fundamental principles, of which the first two are that of emergency and constant comparison. The principle of emergency was respected to the extent that new aspects were added to the theoretical model of Kolb (1984) from the analysis of data collected. In addition, the principle of constant comparison, regarded as the defining feature of the grounded theory approach (Charmaz, 2014; Walsh et al., 2015), was followed to the extent that a continuous interaction was established between emerging data and existing literature, in an effort to built a grounded theory of social reality, i.e., supported by present data and mindful of the existing literature.

The third principle - theoretical sampling - defined in the grounded theory was also an intentional methodological option of this study, as the data sources were chosen based on their relevance in enlarging the scope of the theory. Trying to preserve the diverse representations of each professional/ occupational category studied, participants with different professional experiences and a minimum work practice of two years were selected, so they had opportunities to talk about broader aspects of career trajectory and PD. As state in the section on participants, five professions of each 
occupation were interviewed and the initial analysis of the material collected allowed us to identified common aspects of intra- and intergroup trajectories, enabling the construction of a general theoretical model.

Finally, to meet the fourth principle of the grounded theory, we have used the theoretical saturation. Thus, we started from classes inductively identified by Alceste to begin the dialogue with the base theory. Constant comparison process was used until there were no new elements (adjustments between theory and data). In other words, until the elements of the theory were represented in the data (both denying or confirming the theory) and the classes derived from data could be interpreted by the theoretical framework.

Therefore, the use of the grounded theory allowed for the construction of a model of PD common to different occupational categories. Data diversity deriving from the heterogeneity of these categories allowed the production of a multivariate theory (Araujo \& Estramiana, 2011) on PD, in spite of working on intercategory similarities for the construction of a trans-occupational model. Arrays with content classes obtained from the analyses go beyond the descriptions of words that were predominant in discourses, allowing theoretical insights and generation of concepts (Araujo \& Estramiana, 2011) about the process of PD.

Hence, one can affirm that procedural and propelling elements of PD have distinct natures. Propellers are more concrete Work Context, Motivation, Training/Learning, Relational Elements, Lived Experiences, whereas procedural elements are more abstract. This becomes clear when one observed the adherence between the theoretical model built from data and the experiential learning model of Kolb (1984). Thus, learning from feelings, from concrete experiences, would be represented in the theoretical model by the influences of motivational aspects on the PD. To learn by listening and observing, in a reflective manner (notes and thinks about it), would include, in turn, motivations and relational elements of PD. Learning by thinking, through abstract conceptualization (thinks and conceptualizes) would be related to formal education and training processes. Finally, to learn by doing, through active experimentation (action), would include Lived Experiences. Work Context, as one would expect, is a cross-cutting element at all levels.

These results are also consistent with literature reviews in which career management is associated to different elements, some more related to work contexts and institutions and others focused on personal characteristics of workers (Gallardo-Gallardo et al., 2015; Monteiro \& Mourão, 2017). Thus, we obtained a common core of PD, one that is independent of the occupational categories studied and confirms the central pillars of the growth and improvements processes throughout different careers (Mourão et al., 2014; Paquay et al., 2012; Pimentel, 2007).

The fact the trans-occupational model was constructed from data of only four professions is one of the limitations of this study, as such professions do not represent the diversity of work practices. In this sense, studying the PD processes of other professions would be of paramount importance, also including occupations that do not require higher level training.
Hence, it would be important that further research increase the breadth of fields of practice and, consequently, the number of participants. We also suggest the inclusion of technical occupations since the processes related to training and professional insertion are different to that of professions that require higher level. Finally, given the exploratory nature of this study, we suggest that new research test the model proposed from surveys with member of various occupational categories.

However, despite the fact this study is characterized as a research that requires confirmation and expansion of the model presented, we offer some results with practical implications. For researchers studying the subject, we proposed a model that can be expanded, tested and perfected. For professional working with professional guidance or people development, the study leads to reflections on the propellers of PD for different occupations. We believe, therefore, the results presented can add new elements to the direction of career trajectories or even in assessments regarding career choices. Thus, the study has the potential to contribute to actions aimed at work learning, which involve the own professional, training institutions, employers' organizations, in addition to those responsible for developing public policies related to the subject.

\section{References}

Abbad, G. S., Loiola, E., Zerbini, T., \& Borges-Andrade, J. E. (2013). Aprendizagem em organizações e no trabalho [Learning in organizations and at work]. In L. O. Borges \& L. Mourão (Orgs.), As pessoas, o trabalho $e$ as organizações: Intervenções a partir da psicologia [People, work and organizations: interventions from Psychology] (pp. 497-527). Porto Alegre, RS: Artmed.

American Psychological Association. (2010). Dicionário de psicologia [Dictionary of Psychology]. Porto Alegre, RS: Artmed.

Araujo, B. F. B., \& Estramiana, J. L. A. (2011). Action and social structure in Grounded Theory: Reflections on social sociological psychology. Revista Interamericana de Psicologia/Interamerican Journal of Psychology, 45(3), 381-393. Retrieved from https://www.redalyc.org/ articulo.oa? $\mathrm{id}=28425426008$

Bandura, A. (1977). Social learning theory. New York, NY: Academic Press.

Bell, B. S., Tannenbaum, S. I., Ford, J. K., Noe, R. A., \& Kraiger, K. (2017). 100 years of training and development research: What we know and where we should go. Journal of Applied Psychology, 102(3), 305-323. doi:10.1037/apl0000142

Bernardes, J. S. (2012). Formação em psicologia após 50 anos do primeiro currículo nacional da psicologia: Alguns desafios atuais [Training in Psychology after 50 years of the First National Curriculum of Psychology: some current challenges] [Número Especial]. Psicologia: Ciência e Profissão, 32, 216-231. doi:10.1590/S141498932012000500016 
Bonelli, M. G. (1998). A competição profissional no mundo do direito [Professional competition in the world of law]. Tempo Social, 10(1), 185-214. doi:10.1590/S010320701998000100012

Campbell, J. P., \& Wiernik, B. M. (2015). The modeling and assessment of work performance. Annual Review of Organizational Psychology and Organizational Behavior, 2, 47-74. doi:10.1146/annurevorgpsych-032414-111427

Charmaz, K. (2007). Constructing grounded theory: A practical guide through qualitative analysis. Thousand Oaks, CA: SAGE.

Charmaz, K. (2014). Constructing grounded theory (2th ed.). London, United Kingdom: SAGE.

Claussen, J., Grohsjean, T., Luger, J., \& Probst, G. (2014). Talent management and career development: What it takes to get promoted. Journal of World Business, 49(2), 236-244. doi:10.1016/j.jwb.2013.11.007

Cucina, J. M., \& McDaniel, M. A. (2016). Pseudotheory proliferation is damaging the organizational sciences. Journal of Organizational Behavior, 37(8), 1116-1125. doi:10.1002/job.2117

Dobos, A. (2014). Experiential learning for professional development in the civil service. Procedia - Social and Behavioral Sciences, 116, 5085-5090. doi:10.1016/j. sbspro.2014.01.1078

Gallardo-Gallardo, E., Nijs, S., Dries, N., \& Gallo, P. (2015). Towards an understanding of talent management as a phenomenon-driven field using bibliometric and content analysis. Human Resource Management Review, 25(3), 264-279. doi:10.1016/j.hrmr.2015.04.003

Glaser, B. G., \& Strauss, A. L. (1967). The discovery of grounded theory: Strategies for qualitative research. Chicago, Il: Aldine.

Hill, H. C., Beisiegel, M., \& Jacob, R. (2013). Professional development research: Consensus, crossroads, and challenges. Educational Researcher, 42(9), 476-487. doi:10.3102/0013189X13512674

Högdin, S., \& Kjellman, C. (2014). Research circles: A method for the development of knowledge and the creation of change in practice. Saber \& Educar, 19, 2437. doi:10.17346/se.vol19.91

Illeris, K. (2011). Workplaces and learning. In M. Malloch, L. Cairns, K. Evans, \& B. N. O'Connor (Eds.), The SAGE handbook of workplace learning (pp. 32-45). London, United Kingdom: SAGE.

Jebb, A. T., Parrigon, S., \& Woo, S. E. (2017). Exploratory data analysis as a foundation of inductive research. Human Resource Management Review, 27(2), 265-276. doi:10.1016/j.hrmr.2016.08.003
Kolb, D. A. (1984). Experiential learning: Experience as the source of learning and development. Englewood Cliffs, NJ: Prentice-Hall.

Malhotra, P., \& Singh, M. (2016). Indirect impact of high performers on the career advancement of their subordinates. Human Resource Management Review, 26(3), 209-226. doi:10.1016/j.hrmr.2016.01.002

Monteiro, A. C. F., \& Mourão, L. (2017). Desenvolvimento profissional: A produção científica nacional e estrangeira [Professional development: The national and international scientific production]. Revista Psicologia Organizações e Trabalho, 17(1), 39-45. doi:10.17652/rpot/2017.1.12246

Mourão, L., Porto, J. B., \& Puente-Palácios, K. (2014). Construção e evidências de validade de duas escalas de percepção de desenvolvimento profissional [Evidence of validity of the perception of professional development scale]. Psico-USF, 19(1), 73-85. doi:10.1590/S141382712014000100008

Murphy, C., Klotz, A. C., \& Kreiner, G. E. (2017). Blue skies and black boxes: The promise (and practice) of grounded theory in human resource management research. Human Resource Management Review, 27(2), 291-305. doi:10.1016/j.hrmr.2016.08.006

Noe, R. A., Clarke, A. D. M., \& Klein, H. J. (2014). Learning in the twenty-first-century workplace. Annual Review of Organizational Psychology and Organizational Behavior, 1, 245-275. doi:10.1146/annurev-orgpsych-031413-091321

Paquay, L., Wouters, P., \& Van Nieuwenhoven, C. (2012). A avaliação, freio ou alavanca do desenvolvimento profissional? [The evaluation, brake or lever of professional development?]. In L. Paquay, C. Van Nieuwenhoven, \& P. Wouters (Orgs.), A avaliação como ferramenta de desenvolvimento profissional de educadores [Evaluation as a professional development tool for educators] (pp. 13-39). Porto Alegre, RS: Penso.

Pimentel, A. (2007). A teoria da aprendizagem experiencial como alicerce de estudos sobre desenvolvimento profissional [The experiential learning theory as the basis for the research about professional development]. Estudos de Psicologia (Natal), 12(2), 159-168. doi:10.1590/ S1413-294X2007000200008

Santos, N. R., \& Pais, L. (2014). Structured actions of intentional development. In K. Kraiger, J. Passmore, N. R. Santos, \& S. Malvezzi (Eds.), The Wiley Blackwell handbook of the psychology of training, development, and performance improvement (pp. 398-418). Hoboken, NJ: Wiley-Blackwell.

Spector, P. E., Rogelberg, S. G., Ryan, A. M., Schmitt, N., \& Zedeck, S. (2014). Moving the pendulum back to the middle: Reflections on and introduction to the inductive research special issue of Journal of Business and Psychology. Journal of Business and Psychology, 29(4), 499-502. doi:10.1007/s10869-014-9372-7 
Stewart, C. (2014). Transforming professional development to professional learning. Journal of Adult Education, 43(1), 28-33. Retrieved from https://files.eric.ed.gov/ fulltext/EJ1047338.pdf

Thiry-Cherques, H. R. (2009). Saturação em pesquisa qualitativa: Estimativa empírica de dimensionamento [Saturation in qualitative research: empirical estimation of sizing]. PMKT: Revista Brasileira de Pesquisas de Marketing, Opinião e Mídia, 3, 20-27. Retrieved from http:/www.revistapmkt. com.br/Portals/9/Edicoes/Revista_PMKT_003_02.pdf

Walsh, I., Holton, J. A., Bailyn, L., Fernandez, W., Levina, N., \& Glaser, B. (2015). What grounded theory is... a critically reflective conversation among scholars. Organizational Research Methods, 18(4), 581-599. doi:10.1177/1094428114565028

Woo, S. E., O’Boyle, E. H., \& Spector, P. E. (2017). Best practices in developing, conducting, and evaluating inductive research. Human Resource Management Review, 27(2), 255-264. doi:10.1016/j.hrmr.2016.08.004

Helenita de Araujo Fernandes was a $\mathrm{PhD}$ student of the Programa de Pós-Graduação em Psicologia at the Universidade Salgado de Oliveira, Niteroi-RJ, Brazil.

Luciana Mourão is a Professor of the Programa de PósGraduação em Psicologia at the Universidade Salgado de Oliveira, Niteroi-RJ, Brazil.

Sônia Maria Guedes Gondim is a Professor of the Instituto de Psicologia at the Universidade Federal da Bahia, Salvador-BA, Brazil.

Authors' Contribution:

All authors made substantial contributions to the conception and design of this study, to data analysis and interpretation, and to the manuscript revision and approval of the final version. All the authors assume public responsability for content of the manuscript.

Received: Mar. 19, 2017

1st Revision: Jul. 06, 2017

2nd Revision: Oct. 23, 2017

3rd Revision: Feb. 02, 2018

Approved: Apr. 13, 2018

How to cite this article:

Fernandes, H. A., Mourão, L., \& Gondim, S. M. G. (2019). Professional development: Proposition of a transocupational model from a qualitative study. Paidéia (Ribeirão Preto), 29, e2916. doi: http://dx.doi.org/10.1590/1982-4327e2916 